\title{
Analyzing Recent Research in Computer Mediated Corrective Feedback from the Period 2008-2014
}

\author{
Atef Odeh AbuSa'aleek \\ Unaizah Community College, Qassim University, Qassim, KSA \\ PO. box 4394, Qassim, Unaizah, 51911, KSA \\ E-mail: atefodeh@hotmail.com
}

Received: 02-07-2015

Published: 01-01-2016
Accepted: 09-10-2015

doi:10.7575/aiac.ijalel.v.5n.1p. 178
Advance Access Published: October 2015

URL: http://dx.doi.org/10.7575/aiac.ijalel.v.5n.1p.178

\begin{abstract}
There are different innovations in computer-mediated corrective feedback (henceforth CMCF), which help in offering corrective feedback to the students and proved to have an effect on learners' linguistics outcomes. This study aims to present comprehensive representation of what has been investigated in the area of CMCF. In addition, it aims to analyze the effectiveness of recent $\mathrm{CMCF}$ research regard to adopting different research designs, different technologies, settings \& types of feedback, different participants' characteristics and different language and skill taught. The corpus of analysis consist 23 articles were collected from six well-known journals in the field of CALL from 2008 to 2014 . The findings indicate that $\mathrm{CMCF}$ proved its effectiveness regardless adopting the above-mentioned variables.
\end{abstract}

Keywords: Meta-analysis, computer-mediated communication, Effectiveness of corrective feedback

\section{Introduction}

In recent years, debate was among the researchers about the value and effectiveness of providing corrective feedback to second language learners. Computer-mediated communications have great potential for engage learners in interactive second language learning. CMCF can potential support this communication by providing learners with feedback, which may use to correct their linguistics errors. The rapid development of computer-mediated communication has numerous potential merits of facilitating learning of languages, increases the motivational level among the learners, and helps them to improve their skills quickly. CMCF helps the language learners to overcome their linguistic errors.

The effectiveness of CMCF in language learning has been the concerns of many researchers. Researchers conducted limited researches to explore how CMCF effect learners linguistics outcomes (AbuSeileek, 2013; Sauro, 2009; Dickinson, Eom, Kang, Lee \& Sachs, 2008; Dekhinet, 2008; Sachs \& Suh, 2007) AbuSeileek (2013) states that there are different innovations in CMCF, which help in offering corrective feedback such as word processor and track changes.

The methodology of meta-analysis research presents the analytical tools to deal with the examination of all targeted studies to reach to conclusion about the effectiveness found in CALL applications. The following research of Metaanalysis, contains the structure of research synthesis, quantitative of main studies which provide descriptive statistics (Grgurović, Chapelle, \& Shelley, 2013; Li, 2010; Norris \& Ortega, 2006; Lipsey \& Wilson, 2001).

Lipsey \& Wilson, (2001) as cited in Yun, (2011:41) defined meta-analysis as " a quantitative method to synthesize empirical studies conducted for selected domains, which mainly relies on the results of statistical significance for evaluating and comparing studies compared to narrative literature reviews. It is also comprehensive data-analysis across experimental or quasi-experimental studies that have been previously conducted in a certain field. The collected database information from empirical studies enables a meta-analyst to unveil insightful and potential benefits that have not been found in previous research attempts",

Rosenthal (1995) argued that "meta-analytic reviews are quantitative summaries of research domains that describe the typical strength of the effect or phenomenon, its variability, its statistical significance and the nature of the moderator variables from which one can predict the relative strength of the effect or phenomenon' (p. 183).

Felix (2007) conducted study to investigate the effectiveness of CALL from $2000-2004$. He investigated the strengths and weaknesses in the corpus of analysis and singles out models of excellent design practice. Zhao (2003) conducted meta-analysis to assess whether technology enhancing language education. Zhao also investigated the effectiveness of history and current practices in the application of technology in language education. Russell \& Spada (2006) conducted meta-analysis of analyze 31 studies to investigate the effects of corrective feedback learning L2 grammar.

1.1 Problem of the study 
The problems of the study embedded in many studies in the field of CMCF have misleading titles, poor description of the research design and poor choice of variables to be investigated. Researchers should take into consideration the suitable research designs and the length of the study if they want to draw generalizations about the effectiveness of computer mediated corrective feedback. The present study is unlike previous meta-analyses studies. It is limited to analyze the effectiveness of $\mathrm{CMCF}$ only. This meta-analysis tries to fill the gap in previous researches conducted in computer mediated corrective feedback. Hence, the present meta-analysis conducted on researches published from 2008 to 2014. The effectiveness of CMCF is investigated from different aspects by adopting new variables, which have not been investigated in preceding analyses.

\subsection{Purpose of the Study}

This study aims to present comprehensive representation of what has been investigated in the area of computer mediated corrective feedback. In addition, it aims to analyze the effectiveness of recent CMCF research regard to adopting different research designs, different technologies, settings \& types of feedback, different participants' characteristics and different language and skill taught. More specifically, it seeks to answer the following four research questions:

1. Is effectiveness of CMCF affected by adopting different research designs?

2. Is effectiveness of CMCF affected by adopting different Technologies, settings \& types of feedback?

3. Is effectiveness of CMCF affected by adopting different participants' characteristics?

4. Is effectiveness of $\mathrm{CMCF}$ affected by adopting different language and skill taught?

\section{Theoretical Framework}

\subsection{Meta Analyses of Research on Computer Mediated Corrective Feedback}

Computer-mediated communication in particular has attracted a great deal of interest in corrective feedback studies. Previous researches on CMCF covers many aspects such as comparison between the effectiveness of CMCF and faceto-face feedback, learners' attitude towards CMCF, the effectiveness of CMCF on enhancing language skills and comparison between the effectiveness of different forms of corrective feedback. (see AbuSeileek; 2013; Arnold, Ducate, \& Kost, 2009; Sauro, 2009; Yeha \& Lob, 2009; Dickinson et al., 2008; Dekhinet, 2008; Sachs \& Suh, 2007; Ho \& Savignon, 2007; Loewen \& Erlam, 2006; Skinner \& Austin, 1999; Kern, 1995).

Lightbown \& Spada (1999: 172) defined corrective feedback as "an indication to the learners that his or her use of the target language is incorrect". Schmidt (2001) states that it corrective feedback is "the first step in language building" (p. 31).

Lyster \& Ranta (1997) distinguish six different types of feedback as follows: explicit corrective feedback, recasts, clarification requests, metalinguistic feedback, elicitation and repetition.

AbuSeileek (2013) conducted a study to examine the effect of CMCF types in English language class over time. The learners received CMCF while writing via word processor and track changes. Sauro (2009) examined the effect of two types of $\mathrm{CMCF}$ on the improvement of the knowledge of L2 learners. Sauro used recasts corrective feedback and metalinguistic corrective feedback that provides the learner with information about the nature of the error. The findings revealed that there are no significant effect of both types of feedback on direct or sustained gains in L2 forms knowledge, even though the metalinguistic group showed significant immediate gains relative to the control condition.

Li (2010) conducted a study on meta-analysis on the effectiveness of corrective feedback in second language acquisition. It aims to be an update and complement to previous meta-analyses. Li's study contains 33 studies published between 1988 and 2007, with 11 dissertations and 22 published researches. The findings show that there was generally effect for corrective feedback, the effect was maintained over time, and implicit feedback was more effective than explicit feedback. In addition it shows that studies conducted in lab demonstrates a larger effect than studies conducted in classroom, shorter treatments generated a large effect size than longer treatments and studies conducted in foreign language contexts created larger effect sizes than those in second language contexts.

Lyster \& Saito (2010) conducted meta-analysis on the pedagogical effectiveness of oral corrective feedback on the development of second language and whether its effectiveness diverse based on corrective feedback types, timing of output measures, Language context (second vs. foreign language classroom), treatment length, and age of the sample. The meta-analysis contains on 15 classroom-based studies. The findings showed that corrective feedback had noteworthy and strong effects on development of the target language. The effects were larger for prompts than recasts. While instructional setting does not consider as contributing factor to corrective feedback effectiveness, the effectiveness of long treatments were maintained but not distinguishable from those of short term treatments. In addition, the findings revealed that age factor is effective in favour of younger learners' more than older learners.

Grgurović, et al. (2013) conducted a meta-analysis on the effectiveness studies on computer technology-supported language learning. Thirty-seven studies from 1970 to 2006 were included. The findings show that the overall results favoured the technology-supported pedagogy, with a small, positive and statistically significant effect size. Second/foreign language context computer based technology was found to be effective as instruction without technology, and the studies used accurate research designs of CALL groups outperformed the non-CALL groups. 


\section{Method}

\subsection{Identification of Studies}

The researcher initially conduct extensive search for CMCF studies from number of resources for meta- analysis. A number of resources were used to search for studies relevant to this meta-analysis study. The researcher relied on six well-known journals in the field of CALL such ReCALL, Computer Assisted Language Learning (CALL), Language learning \& Technology, Journal of Computer Assisted Learning, Computer \& Education and The JALT CALL Journal. The search in the mentioned journals covered the period from 2008 to 2014. The followings are the key words used for these searches 'computer mediated corrective feedback', 'types of feedback', 'implicit and explicit feedback', 'negative feedback', 'recasts', 'metalinguistic feedback'.

\subsection{Criteria for Inclusion}

- The studies included in the present analysis had to be published from 2008 to 2014 .

- The study should report results of about the computer mediated corrective feedback.

- The study should include only feedback mediated via computer.

- The study should focus on computer feedback at least in one of the language skills.

\subsection{Coding of the Studies}

The researcher tries to provide details information on the included studies included. The researcher used twelve coding criteria:

- Language(s) taught

- Native language of the participants

- Technology used

- Language skills

- Participants' language proficiency

- Setting

- Research design

- Number of participants

- Length of treatment

- Effectiveness over time

- Feedback's type

- Participants' gender

\subsection{Procedures for Data Analysis}

A total of 23 articles were collected from six well-known journals in the field of CALL (see Appendix A). Appendix A. includes the research studies about CMCF included in the analysis covered the period from 2008 to 2014 . Figure 1 below presents the distribution of the articles among the journals. The researcher analyzes the date in four tables. Table 1 includes the distribution of the studies based on their research design.

Table 2 includes the distribution of the studies based on the language and skills taught. Table 3 includes the distribution of the studies based on the participants' characteristics such as their numbers in the articles, their first language, level of proficiency, and their gender. Table 4 presents the distribution of the studies based on the technology used in the experiments, settings and the type of the feedback given to the participants.

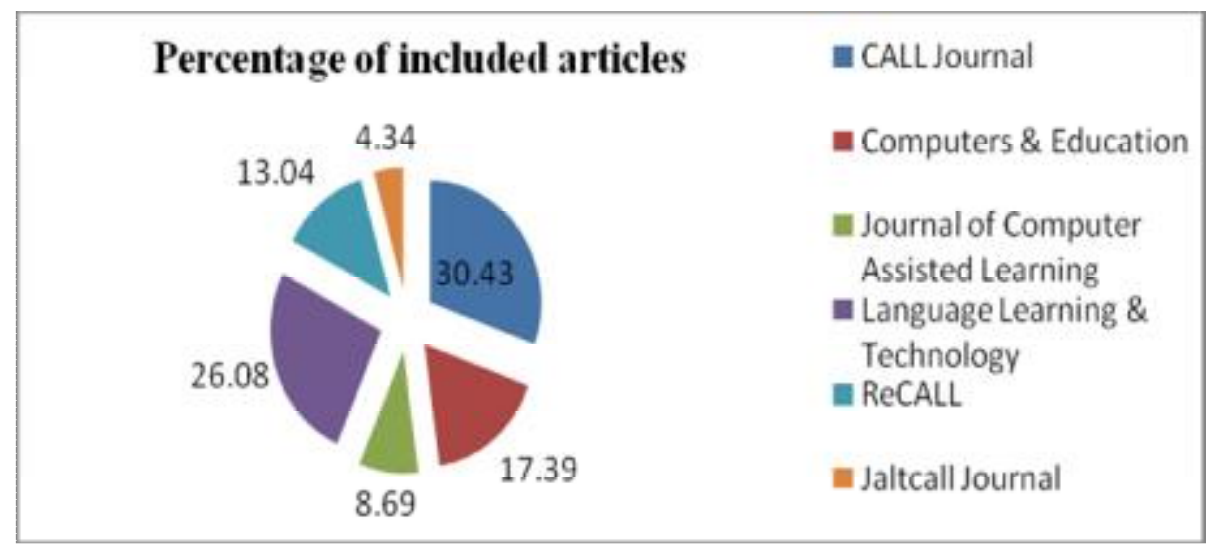

Figure1. The distribution of the articles among the journals

\section{Results}

4.1 Overview of Effectiveness of Computer Mediated Feedback and Research Design

Table 1 below presents the distribution of the 23 studies based on two categories the first category includes four main research designs such as pre-experimental, quasi-experimental, experimental and non-experimental. The second 
category includes case study, within-subjects design, between-subjects design, factorial experimental design, pre-test and post-test control group, questionnaires/ interviews, non- equivalent comparison group, analysis of transcript.

In the distribution of the studies, the researcher found that 13 studies come under non-experimental design. Five studies are pre-experimental design. Three studies are experiential design. Two studies are quasi-experimental, experimental. This indicates the strength of CMCFstudies hence the two categories were found in majority of the included articles.

In addition, the findings indicate that the following studies used two research designs (Cornillie, Clarebout, \& Desmet, 2012; de Vries, Cucchiarini, Bodnar, Strik, \& Hout, 2014; Dekhinet, 2008; Dippold, 2009; Topping, Dehkinet, Blanch, Corcelles, \& Duran, 2013; Wigham \& Chanier, 2013).

The following study use three-research design, between-subjects design, analysis of transcript and questionnaires (see Vinagre \& Munoz, 2011). Regard the effectiveness of computer mediated feedback all the 23 studies included in the analysis reported the effectiveness of computer mediated feedback over time. Length of treatment as mentioned in Appendix B ranged from 1 year (see Nicolaidou, 2013; Tanes, King, \& Remnet, 2011) to ninety minutes (see de Vries et al., 2014).

Table 1. Distribution of the studies based on research design*

\begin{tabular}{|c|c|c|c|c|}
\hline Research design & $\begin{array}{c}\text { Pre- } \\
\text { experimental }\end{array}$ & $\begin{array}{c}\text { Quasi- } \\
\text { experimental }\end{array}$ & Experimental & $\begin{array}{c}\text { Non- } \\
\text { experimental }\end{array}$ \\
\hline Case study & 1319 & & & $4 * * 8 * * 9101223$ \\
\hline Within-subjects design & 21 & & 22 & 3 \\
\hline Between-subjects design & 15 & $17 * *$ & & $1118^{* * *}$ \\
\hline Factorial experimental design & & & & $720 * *$ \\
\hline Pre-test - post-test control group & & 2 & 1 & \\
\hline Questionnaires/ interviews & & & $5 * *$ & $4 * * 6 * * 8 * * 18 * * *$ \\
\hline $\begin{array}{l}\text { Non- equivalent comparison group } \\
\text { design }\end{array}$ & 14 & & $5 * *$ & \\
\hline Analysis of transcript & & $17 * *$ & & $6 * * 1618 * * * 20 * *$ \\
\hline Total & 5 & 2 & 3 & 13 \\
\hline
\end{tabular}

Note: numbers represent the studies' ID.

*See the definitions in Appendix B

** This study use two research designs

*** This study use three research designs

\subsection{Technology Used, Setting \& Types of Computer Mediated Corrective Feedback}

Table 2 below illustrates the distribution of the 23 studies based on three categories the first category includes the technology used in providing the feedback to the participants. Hence, technology for mediated corrective feedback can be used in several ways.

\subsubsection{Technology Used}

The researcher coded the studies included in the analysis in the following categories:

1. Computer application (word processor)

2. Synchronous \& A synchronous CMC

3. Web

4. Intelligent CALL CMC + Automatic speech recognition (ASR)

5. CALL specific software

The findings presented in Table 2 shows that most studies used synchronous \& synchronous CMC in delivering different types of feedback (see Bower \& Kawaguchi 2011; Dekhinet, 2008; Murphy, 2010; Sauro, 2009; Tanes et al., 2011; Vinagre \& Munoz, 2011; Wigham \& Chanier, 2013; Zourou, 2009). and web (see Cornillie et al., 2012; Dippold, 2009; Engwall, 2012; Guichon, Bétrancourt \& Prié, 2012; Monteiro, 2014; Nicolaidou, 2013; Topping et al., 2013; Yang \& Meng, 2013). In addition, only two studies used computer application software such as word processors (see AbuSeileek, 2013; AbuSeileek \& Abualsha'r, 2014).

Moreover, two studies used CALL specific software (see Patten \& Edmonds, 2013; Yeh \& Lo, 2009). Finally, only three studies used Intelligent CALL software to provide feedback to the students (see de Vries et al., 2014; Dickinson et al., 2008; Wang \& Young, 2014).

\subsubsection{Setting}

The researcher found only three settings in which studies about computer corrective feedback were conducted and coded in the following categories.

1. College

2. School

3. Language centre 
Table 2 below shows the distribution of the 23 studies based on three categories college, school and language centre. The findings indicate that majority of the studies were conducted in graduation (college) setting (see AbuSeileek, 2013; AbuSeileek \& Abualsha'r, 2014; Bower \& Kawaguchi 2011; Dekhinet, 2008; ) and that school (see Nicolaidou, 2013; Topping et al., 2013; Vinagre \& Munoz, 2011), language centre settings appear to be underrepresented in CMCF studies (see de Vries et al., 2014; Monteiro, 2014).

In addition, the findings indicate that only three studies did not report the educational setting (see Engwall, 2012; Patten, \& Edmonds, 2013; Zourou, 2009). Moreover, the findings show that only one study conducted in two educational settings (see Wang \& Young, 2014).

\subsubsection{Types of Computer Mediated Corrective Feedback}

This section is devoted to the analysis of types of computer mediated corrective feedback. Table 2 below exemplify the distribution of the 23 studies based on types of computer mediated corrective feedback. The types of CMCF were coded in eight categories as follows:

1. Explicit \& Implicit Feedback only

2. Recast

3. Peer Feedback

4. Focused

5. Meta-linguistic feedback

6. Audio-visual Feedback

7. Elaborative Feedback

8. Mixed types of Feedback (explicit \& implicit, recast, peer feedback, meta-linguistic)

The findings presented in Table 2 shows that many studies used explicit \& implicit feedback only (see AbuSeileek, 2013; Cornillie et al., 2012; de Vries et al., 2014; Dekhinet, 2008; Wang \& Young, 2014) and mixed types of feedback (see AbuSeileek \& Abualsha'r, 2014; Monteiro, 2014; Sauro, 2009; Tanes et al., 2011; Wigham \& Chanier, 2013). In addition, Dippold (2009) \& Murphy (2010) examined the elaborative CMCFand Nicolaidou (2013), Topping et al., (2013); Vinagre \& Munoz (2011); Yang \& Meng (2013); investigated computer mediated peer feedback. Moreover, Yeh \& Lo (2009) examined computer mediated meta-linguistic feedback. Guichon et al., (2012) investigated computer mediated recast feedback. Finally only two studies investigated audio-visual feedback (see Engwall, 2012; Patten \& Edmonds, 2013).

Table 2. Distribution of the studies based on technological utilization, setting \& types of CMCFB

\begin{tabular}{|c|c|c|c|c|c|}
\hline Technology used & $\begin{array}{l}\text { Article } \\
\text { No. }\end{array}$ & Setting & Article No. & $\begin{array}{l}\text { Types of } \\
\text { Feedback }\end{array}$ & Article No. \\
\hline $\begin{array}{l}\text { Computer application } \\
\text { (word processor) }\end{array}$ & 12 & College & $\begin{array}{rrlllll}1 & 2 & 3 & 4 & 6 & 7 & 8 \\
10 & 12 & 15 & 16 \\
19^{*} & 20 & 21 & 22\end{array}$ & $\begin{array}{l}\text { Explicit \& } \\
\text { Implicit Feedback } \\
\text { only }\end{array}$ & 145619 \\
\hline $\begin{array}{l}\text { Synchronous \& A } \\
\text { synchronous CMC }\end{array}$ & 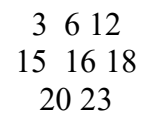 & Language centre & 511 & $\begin{array}{l}\text { Recast } \\
\text { Peer Feedback }\end{array}$ & $\begin{array}{c}10 \\
13171821\end{array}$ \\
\hline Web & 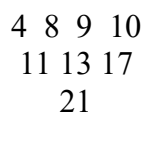 & School & $13171819 *$ & $\begin{array}{l}\text { Focused } \\
\text { Meta-linguistic } \\
\text { feedback }\end{array}$ & $\begin{array}{l}723 \\
22\end{array}$ \\
\hline $\begin{array}{l}\text { Intelligent CALL CMC } \\
+ \text { Automatic speech } \\
\text { recognition (ASR) }\end{array}$ & 5719 & Not reported & 91423 & $\begin{array}{l}\text { Audio- } \\
\text { visual Feedback } \\
\text { Elaborative } \\
\text { Feedback }\end{array}$ & $\begin{array}{l}914 \\
812\end{array}$ \\
\hline CALL specific software & 1422 & & & $\begin{array}{l}\text { Mixed types of } \\
\text { Feedback } \\
\text { Not reported }\end{array}$ & $\begin{array}{c}2 * * 11 * * 15^{* *} \\
16^{* *} 20 * * \\
3\end{array}$ \\
\hline
\end{tabular}

*This study contains two settings

**This study contains more than one type of feedback

4.3 Participants' Characteristics

Table 3 below presents the distribution of participants' characteristics based on four categories; participants' first language, their numbers in the study, level of proficiency and their gender and coded as follow:

4.3.1 Participant's first language

The participants' first language had twelve subcategories: Arabic, Caucasian, Dutch, Japanese, Korean, German, Swedish, French, Chinese, Turkish, Portuguese, and mixed L1. The findings reveled that the participants in many studies belong to the same L1 for instance all the participants speak Arabic language as first language (see AbuSeileek, 
2013; AbuSeileek \& Abualsha'r, 2014) whereas the participants in de Vries et al., study speak Dutch Arabic, Chinese, Dari, English, French, German, Indonesian, Italian, Russian, Luganda, Polish, Portuguese, and Romanian. Table 3 demonstrate that the participants' first language does not have impact on the effectiveness of CMCF over time. In other words, $\mathrm{CMCF}$ has proved its effectiveness over time regardless the first language of the participants.

4.3.2 Number of Participants

The total number of participants in CMCF studies, which included in the analysis, is 910 students. Table 3 below presents the distribution of number of participants based on six subcategories as follow:
1. $1-10$
2. $11-20$
3. $21-30$
4. $31-50$
5. $50-70$
6. $70+$

The findings indicate that the number of participants range from less than ten students (see Dekhinet, 2008; Engwall, 2012; Patten \& Edmonds, 2013; Tanes et al., 2011; Vinagre \& Munoz, 2011) to more than 70 students in the study (see Cornillie et al., 2012; Murphy, 2010). Table 3 demonstrate that the number of the participants in the studies does not make a difference on the effectiveness of CMCF over time.

4.3.3 Level of Proficiency

The researcher coded the $\mathrm{CMCF}$ studies included in the analysis based on level of proficiency in the following categories:
1. Advanced
2. Intermediate
3. Beginners
4. Mixed

Table 3 presents the findings for these categories. The findings indicate that the level of proficiency of the participants was intermediate in the majority of the studies (see AbuSeileek, 2013; AbuSeileek \& Abualsha'r, 2014; Cornillie et al., de Vries et al., 2014; Dekhinet, 2008; Patten \& Edmonds, 2013; Wang \& Young, 2014; Wigham \& Chanier, 2013). The findings the number of the studies where the participants' level of proficiency is advanced level is (5 studies), mixed level of proficiency is (5 studies) and beginners level is (4 studies). In addition, the findings showed that only one study did not mention the level of proficiency for the sample of the study (see Engwall, 2012). CMCFhad proved its effectiveness over time regardless the participants' level of proficiency.

\subsubsection{Gender of Participants}

Gender of the participant is the last category of participants' characteristics. The findings indicate that it is clear-cut that $\mathrm{CMCF}$ is effective regardless of participants' gender. Furthermore, Table 3 shows that the gender of the participants in majority of the studies (11 studies) was both male and female. In addition, findings indicate that only the gender of the sample wad female in one study (see Patten \& Edmonds, 2013). Moreover, the analysis found that (11 studies) did not mention the gender of the participants.

Table 3. Distribution of the studies based on participants' characteristic

\begin{tabular}{|c|c|c|c|c|c|c|c|c|c|}
\hline $\begin{array}{c}\text { Participants } \\
\text { L1 }\end{array}$ & $\begin{array}{c}\text { Article } \\
\text { No. }\end{array}$ & $\begin{array}{c}\text { Participants } \\
\text { L1 }\end{array}$ & $\begin{array}{c}\text { Article } \\
\text { No. }\end{array}$ & $\begin{array}{c}\text { No. of } \\
\text { participants }\end{array}$ & $\begin{array}{c}\text { Article } \\
\text { No. }\end{array}$ & $\begin{array}{c}\text { Level of } \\
\text { Proficiency }\end{array}$ & $\begin{array}{c}\text { Article } \\
\text { No. }\end{array}$ & Gender & $\begin{array}{c}\text { Article } \\
\text { No. }\end{array}$ \\
\hline Arabic & 12 & Chinese & $\begin{array}{c}1921 \\
22\end{array}$ & $1-10$ & $\begin{array}{ccc}6 & 9 & 14 \\
16 & 18\end{array}$ & Advanced & $\begin{array}{c}81016 \\
1718\end{array}$ & Male & 0 \\
\hline Caucasian & 16 & Portuguese & 11 & $11-20$ & 81320 & Intermediate & $\begin{array}{c}1245 \\
61419 \\
20\end{array}$ & Female & 14 \\
\hline Dutch & 4 & Turkish & 13 & $21-30$ & 51015 & Beginners & $\begin{array}{c}71113 \\
22\end{array}$ & Mixed & $\begin{array}{c}1245 \\
611 \\
1516 \\
1819 \\
20\end{array}$ \\
\hline Japanese & 1214 & Mixed L1* & $\begin{array}{cc}356 \\
1517 \\
1820 \\
23\end{array}$ & $31-50$ & $\begin{array}{c}31117 \\
1922\end{array}$ & Mixed & $\begin{array}{c}31215 \\
2123\end{array}$ & $\begin{array}{c}\text { Not } \\
\text { reported }\end{array}$ & $\begin{array}{c}3789 \\
1012 \\
1317 \\
2122 \\
23\end{array}$ \\
\hline Korean & 7 & & & $50-70$ & 1221 & $\begin{array}{c}\text { Not } \\
\text { reported }\end{array}$ & 9 & & \\
\hline German & 8 & & & $70+$ & 412 & & & & \\
\hline Swedish & 9 & & & $\begin{array}{c}\text { Not } \\
\text { reported }\end{array}$ & 723 & & & & \\
\hline French & 10 & & & & & & & & \\
\hline
\end{tabular}




\section{Language and Skill Taught}

This section is devoted to the findings of the related to the language and skill taught in the studies of computer mediated corrective feedback. Table 4 presents the findings of distribution of 23 studies on two categories. The first category is language taught and it consists of seven subcategories English, Japanese, Dutch, Korean, French, Swedish, Spanish and German. Table 4 demonstrates that English (17 studies) represents the most frequently taught language followed by French, German and Spanish. In addition Japanese, Korean, Dutch, Swedish considered less commonly taught language.

Whereas the second category is skills taught and it consist of nine subcategories pronunciation, speaking, reading, writing, communication, vocabulary, grammar, listening and integrated skills. Moreover, Table 4 presents the findings regard the skills taught to the respondents when delivering feedback via computer. It found that the most frequently skill taught in the investigated studies is writing with seven studies followed by integrated skills then speaking with five studies, three studies focused on grammar and two studies focused on pronunciation. The study also found that only one study focused on reading skill and one study on communication. Finally, there was no single study focused on vocabulary and listening skill separately.

Table 4. Distribution of the studies based on language and skills taught

\begin{tabular}{|c|c|c|c|c|c|c|c|c|c|}
\hline & English & Japanese & Dutch & Korean & French & Swedish & Spanish & German & Total \\
\hline Pronunciation & 14 & & & & & 9 & & & 2 \\
\hline Speaking & 45620 & & & & 20 & & & & 4 \\
\hline Reading & 12 & & & & & & & & 1 \\
\hline Writing & 12132122 & & & & 10 & & 18 & 18 & 7 \\
\hline Communication & & & & & 23 & & & & 1 \\
\hline Vocabulary & & & & & & & & & 0 \\
\hline Grammar & 1115 & & 5 & 7 & & & & & 3 \\
\hline Listening & & & & & & & & & 0 \\
\hline \multirow[t]{2}{*}{ Integrated Skills } & 163 & 3 & & & & & 17 & 8 & 5 \\
\hline & 1719 & & & & & & & & \\
\hline
\end{tabular}

\section{Discussion of the Findings}

The present meta-analysis tries to confirm whether adopting different research designs, different technologies, settings \& types of feedback, different participants' characteristics and different language and skill taught affect the effectiveness of recent CMCF research.

Based on the findings of this meta- analysis, it can be affirmed that CMCF proved its effectiveness regardless adopting different research designs, different technologies, settings \& types of feedback, different participants' characteristics and different language and skill taught. Li (2010) in his article entitled the effectiveness of corrective feedback in SLA proved that there was effect for corrective feedback and the effect was preserved over time. In addition, the studies based computer corrective feedback present large effect.

This study examined whether CMCF research is affected by adopting different research designs. The research designs found in the analysis includes two categories, the first category includes pre-experimental, quasi-experimental, experimental and non-experimental. The second category includes case study, within-subjects design, between-subjects design, factorial experimental design, pre-test and post-test control group, questionnaires/ interviews, non- equivalent comparison group, analysis of transcript.

The findings confirmed that $\mathrm{CMCF}$ proved its effectiveness regardless adopting different research designs. Hence, many studies used two research designs (see for instance, Cornillie, Clarebout, \& Desmet, 2012; de Vries et al., 2014; Dekhinet, 2008). Other studies use three-research design, between-subjects design, analysis of transcript and questionnaires (see for instance, Vinagre \& Munoz, 2011).

Even though $\mathrm{CMCF}$ proved its effectiveness regardless adopting different research designs but the analysis found poor description of research design. For instance, Dickinson et. al (2008) design a parser-based system, which provides feedback on particle usage. There was lake of information about the research design used in the study, such as test (prepost test). The study gives no information about the adopted statistical analysis to prove the effectiveness of the designed software in providing feedback. In addition, number of the participants and their gender and length of the treatment are not mentioned. Another study (Zourou, 2009) does not provide information on research design used in the study, such as test (pre-post test), statistical analysis used in the study, number of the participants and their gender and length of the treatment. 
The study by AbuSeileek (2013) is an excellent example of well research designed. He conducted a study to examine the effect of CMCF types in English language class over time. His study was conducted over 3 hours by 12 weeks. Number of the participants, their gender and length of the treatment were mentioned in the study. This study conducted in college setting. The students were assigned randomly into three treatment conditions. The same teacher taught all the groups. Pre-test, immediate post-test and delayed post-test were conducted. The research followed the appropriate statistical analyses, including instrument validity and reliability, and statistical analyses (mean, standard deviation and analysis of variance (ANOVA)).

With regard to the discussion of the second question, whether the effectiveness of CMCF affected by adopting different technologies, settings \& types of feedback. The findings confirmed that CMCF proved its effectiveness regardless adopting different technologies, settings \& types of feedback. The investigated studies used different technologies such as synchronous \& synchronous CMC (for instance, Bower \& Kawaguchi 2011; Dekhinet, 2008; Murphy, 2010), computer application software such as word processors (see AbuSeileek, 2013; AbuSeileek \& Abualsha'r, 2014), CALL specific software (see Patten \& Edmonds, 2013; Yeh \& Lo, 2009) and Intelligent CALL software (see de Vries et al., 2014).

In addition, the investigated studies were conducted in college setting (for instance, AbuSeileek, 2013) school (see Nicolaidou, 2013) and language centre settings (see Monteiro, 2014). The findings indicate that majority of the studies were conducted in college setting. Moreover, the investigated studies investigated the following types of CMCF explicit \& implicit feedback only, recast, peer feedback, focused, meta-linguistic feedback, audio-visual feedback, elaborative feedback, mixed types of feedback (explicit \& implicit, recast, peer feedback, meta-linguistic).

Even though CMCF proved its effectiveness regardless adopting different technologies, settings \& types of feedback, hence it found that For instance, Engwall (2012) conducted experiment on computer-assisted pronunciation via a virtual pronunciation teacher, but there was lake of information about where this study conducted at college, school or language centre.

With regard to the discussion of the third question, whether the effectiveness of CMCF affected by adopting different participants' characteristics. The characteristics of the participants based on four categories; participants' first language, their numbers in the study, level of proficiency and their gender. The findings affirmed that CMCF demonstrate its effectiveness regardless adopting different participants' characteristics.

In spite of the fact, that CMCF proved its effectiveness regardless adopting different participants' characteristics but the analysis found poor description of different participants' characteristics. For instance, Patten \& Edmonds (2013) check the effect of spectrographic visual feedback on Japanese speakers in the production of American $/ \mathrm{r} / \mathrm{using}$. The number of the participants in their study was only two native speakers of Japanese. The small number of participants raises suspicion on the effectiveness of the experiment. Moreover, Engwall (2012) in his study about computer-assisted pronunciation did not mention the level of proficiency of the participants.

Unexpectedly large numbers of studies do not mention the gender of the participants. For instance, (see Bower \& Kawaguchi 2011; Dickinson et al., 2008; Dippold, 2009; Engwall, 2012; Guichon et al., 2012; Murphy, 2010; Topping et al., 2013; Yang \& Meng, 2013; Zourou, 2009).

Furthermore, this study examined whether $\mathrm{CMCF}$ research is affected by adopting different languages and skills taught. The analysis of 23 studies found that the computer feedback was provided in the following seven languages English, Japanese, Dutch, Korean, French, Swedish, Spanish and German. It found that English is the most taught language for instance (see AbuSeileek, 2013; de Vries et al., 2014; Dickinson et al., 2008; Guichon et al., 2012). The analysis shows that most of the CMCF covers most of the language skills. Even though CMCF proved its effectiveness regardless, adopting different languages and skills taught. The study also found that only one study focused on reading skill (Murphy, 2010) and one study on communication (Zourou, 2009). At last, there was no single study focused on vocabulary and listening skill separately.

\section{Conclusion, Limitations and Recommendations}

In recent years, debate was among the researchers about the value and effectiveness of providing corrective feedback via computer to second language learners. The findings of this study confirmed that CMCF proved its effectiveness regardless adopting different research designs, different technologies, settings \& types of feedback, different participants' characteristics and different language and skill taught.

Researchers should take into consideration the suitable research designs and the length of the study if they want to draw generalizations about the effectiveness of computer mediated corrective feedback.

This study is limited present meta-analysis conducted on researches published on CMCF from 2008 to 2014. Another limitation is that only 23 studies were collected from six well-known journals in the field of CALL. Therefore, the findings of this study cannot be generalized beyond the 23 studies. This study recommends further investigation in the effectiveness of CMCF to verify or refute the findings of this study. Moreover, this study recommends that more studies should be conducted to investigate the effectiveness of computer mediated corrective in teaching vocabulary and listening. 


\section{References}

Arnold, N., Ducate, L., \& Kost, C. (2009). Collaborative writing in wikis: Insights from culture projects in intermediate German classes. The next generation: Social networking and online collaboration in foreign language learning, 115144.

Ellis, R. (2009). Corrective feedback and teacher development. L2 Journal, 1(1), 3-18.

Felix, U. (2005). Analysing recent CALL effectiveness research-towards a common agenda. Computer Assisted Language Learning, 18(1-2), 1-32.

Grgurović, M., Chapelle, C. A., \& Shelley, M. C. (2013). A meta-analysis of effectiveness studies on computer technology-supported language learning. ReCALL, 25(02), 165-198.

Ho, M., \& Savignon, S. (2007). Face-to-face and computer-mediated peer review in EFL writing. CALICO Journal, 24(2), 269-290.

Kern, R. G. (1995). Restructuring classroom interaction with networked computers: effects on quantity and characteristics of language production. The Modern Language Journal, 79 (4), 457-476.

Lightbown, P. M., \& Spada, N. (1999). How languages are learned. Oxford, UK: Oxford

Loewen, S., \& Erlam, R. (2006). Corrective feedback in the chatroom: An experimental study. Computer Assisted Language Learning, 19(1), 1-14.

Lyster, R., \& Ranta, L. (1997). Corrective feedback and learner uptake. Studies in second language acquisition, 19(01), 37-66.

Lyster, R., \& Saito, K. (2010). Oral feedback in classroom SLA. Studies in Second Language Acquisition, 32(02), 265302.

Mark W. Lipsey, \& Wilson, D. B. (2001). Practical meta-analysis (Vol. 49). Thousand Oaks, CA: Sage publications.

Norris, J. M., \& Ortega, L. (Eds.). (2006). Synthesizing research on language learning and teaching (Vol. 13). John Benjamins Publishing.

Rosenthal, R. (1995). Writing meta-analytic reviews. Psychol. Bull. 118 (2):183-92

Russell, J., \& Spada, N. (2006). The effectiveness of corrective feedback for the acquisition of L2 grammar. Synthesizing research on language learning and teaching, 133-164.

Sachs, R., \& Suh, B. (2007). Textually enhanced recasts, learner awareness, and L2 outcomes in synchronous computer-mediated interaction. In A. Mackey (Ed.), Conversational interaction in second language acquisition: A collection of empirical studies (pp. 197-227). Oxford: Oxford University Press.

Schmidt, R. (2001). Attention. In P. Robinson (Ed.), Cognition and second language instruction (pp. 3- 32). Cambridge: Cambridge University Press.

Skinner, B., \& Austin, R. (1999). Computer conferencing-Does it motivate EFL students? ELT Journal, 53(4), 270279.

Yeha, Sh., \& Lob, J. (2009). Using online annotations to support error correction and corrective feedback. Computer \& Education, 52(4), 882-892

Yun, J. (2011). The effects of hypertext glosses on L2 vocabulary acquisition: A meta-analysis. Computer Assisted Language Learning, 24(1), 39-58.

Zhao, Y. (2013). Recent developments in technology and language learning: A literature review and metaanalysis. CALICO journal, 21(1), 7-27.

\section{Appendix 1}

\section{Research Studies Included in the Analysis}

1. AbuSeileek, A. F. (2013). Using track changes and word processor to provide corrective feedback to learners in writing. Journal of Computer Assisted Learning, 29(4), 319-333. doi: 10.1111/jcal.12004

2. AbuSeileek, A., \& Abualsha'r, A. (2014) Using peer computer-mediated corrective feedback to support EFL learners' writing. Language Learning \& Technology 18(1), 76-95. Retrieved from http://1lt.msu.edu /issues /February 2014/abuseileekabualshar.pdf

3. Bower, J., \& Kawaguchi, S. (2011). Negotiation of meaning and corrective feedback in Japanese/English eTandem. Language Learning \& Technology, 15(1), 41-71.

4. Cornillie, F., Clarebout, G., \& Desmet, P. (2012). Between learning and playing? Exploring learners' perceptions of corrective feedback in an immersive game for English pragmatics. ReCALL, 24(03), 257-278. DOI: $\quad$ 10.1017/ S095 8344012000146

5. de Vries, B. P., Cucchiarini, C., Bodnar, S., Strik, H., \& van Hout, R. (2014). Spoken grammar practice and feedback in an ASR-based CALL system.Computer Assisted Language Learning, 1-27. DOI: 
6. Dekhinet, R. (2008). Online enhanced corrective feedback for ESL learners in higher education. Computer Assisted Language Learning, 21(5), 409-425. DOI: $10.1080 / 09588220802447669$

7. Dickinson, M., Eom, S., Kang, Y., Lee, C. M., \& Sachs, R. (2008). A balancing act: how can intelligent computer-generated feedback be provided in learner-to-learner interactions?. Computer Assisted Language Learning, 21(4), 369-382. DOI: 10.1080/09588220802343702

8. Dippold, D. (2009). Peer feedback through blogs: Student and teacher perceptions in an advanced German class. ReCALL, 21(01), 18-36. DOI: 10.1017 /S 095834 400900010X,

9. Engwall, O. (2012). Analysis of and feedback on phonetic features in pronunciation training with a virtual teacher. Computer Assisted Language Learning, 25(1), 37-64. DOI: 10.1080/09588221.2011.582845

10. Guichon, N., Bétrancourt, M., \& Prié, Y. (2012). Managing written and oral negative feedback in a synchronous online teaching situation. Computer assisted language learning, 25(2), 181-197. DOI: $10.1080 / 09588221.2011 .636054$

11. Monteiro, K. (2014). An experimental study of corrective feedback during video-conferencing. Language Learning \& Technology, 18(3), 56-79. Retrieved from http://1tt.msu.edu/issues/october2014/monteiro.pdf

12. Murphy, P. (2010). Web-based collaborative reading exercises for learners in remote locations: the effects of computer-mediated feedback and interaction via computer-mediated communication. $\operatorname{ReCALL}, 22(02), 112-$ 134. DOI: $10.1017 / \mathrm{S} 0958344010000030$

13. Nicolaidou, I. (2013). E-portfolios supporting primary students' writing performance and peer feedback. Computers \& Education, 68, 404-415. http://dx.doi.org/ 10.1016/j.compedu.2013. 06.004

14. Patten, I., \& Edmonds, L. A. (2013). Effect of training Japanese L1 speakers in the production of American English/r/using spectrographic visual feedback. Computer Assisted Language Learning. 1-19. DOI: 10.1080 /095882 $21.20 \quad 13.839570$

15. Sauro, S. (2009). Computer-mediated corrective feedback and the development of L2 grammar. Language Learning \& Technology, 13(1), 96-120.

16. Tanes, Z., Arnold, K. E., King, A. S., \& Remnet, M. A. (2011). Using Signals for appropriate feedback: Perceptions and practices. Computers \& Education,57(4), 2414-2422. doi:10.1016/j.compedu.2011.05.016

17. Topping, K. J., Dehkinet, R., Blanch, S., Corcelles, M., \& Duran, D. (2013). Paradoxical effects of feedback in international online reciprocal peer tutoring. Computers \& Education, 61, 225-231. http://dx.doi.org/ 10.1016/j. Comp edu. 2012.10.002

18. Vinagre, M., \& Munoz, B. (2011). Computer-mediated corrective feedback and language accuracy in telecollaborative exchanges. Language Learning \& Technology, 15(1), 72-103.

19. Wang, Y. H., \& Young, S. C. (2014). Effectiveness of feedback for enhancing English pronunciation in an ASR-based CALL system. Journal of Computer Assisted Learning. doi: 10.1111/jcal.12079

20. Wigham, C. R., \& Chanier, T. (2013). Interactions between text chat and audio modalities for L2 communication and feedback in the synthetic world Second Life. Computer Assisted Language Learning, 124. DOI: $10.1080 / 09588221.2013 .851702$

21. Yang, Y.-F., \& Meng, W.-T. (2013). The effects of online feedback on students' text revision. Language Learning \& Technology, 17(2), 220-238. Retrieved from http://llt.msu.edu/issues/june2013/yangmeng.pdf

22. Yeh, S. W., \& Lo, J. J. (2009). Using online annotations to support error correction and corrective feedback. Computers \& Education, 52(4), 882-892. doi:10.1016/j. compedu. 2008. 12.014

23. Zourou, K. (2009). Corrective feedback in telecollaborative L2 learning settings: Reflections on symmetry and interaction. The Jaltcall Journal, 5(1), 3-20.

\section{Appendix 2}

Definition of research design terminology as cited in Felix (2007:26-27)

PRE-EXPERIMENTAL DESIGN May have pre- and post-treatment tests, but lacks a control group (Nunan, 1992, p. 41).

QUASI-EXPERIMENTAL DESIGN Has both pre- and post-tests and experimental and control groups, but no random assignment of subjects (Nunan, 1992, p. 41).

EXPERIMENTAL DESIGN Has both pre- and post-tests, experimental and control groups, and random assignment of subjects (Nunan, 1992, p. 41).

NON-EXPERIMENTAL DESIGN Refers to situations in which a presumed cause and effect are identified and measured but in which other structural features of experiments, such as random assignment, pre-tests and control groups are missing. Instead reliance is placed on measuring alternative explanations individually and

then statistically controlling for them.

ONE-GROUP PRE-TEST - POST-TEST DESIGN A single pre-test observation is taken on a group of respondents, treatment then occurs, and a single post-test observation on the same measure follows (Shadish et al., 2002, p. 108). 
NON-EQUIVALENT COMPARISON GROUP DESIGN Uses a treatment group and an untreated comparison group, with both pre-test and post-test data gathered on the same units (Shadish et al., 2002, p. 136).

POST-TEST ONLY CONTROL GROUP DESIGN Incorporates just the basic elements of experimental design: random assignment of subjects to treatment and control groups, introduction of the independent variable to the treatment group, and a post-treatment measure of the dependent variable for both groups (Singleton Jr. et

al., 1993, p. 222).

PRE-TEST - POST-TEST CONTROL GROUP DESIGN A design which measures the experimental group before and after the experimental treatment. A control group is measured at the same time, but does not receive the experimental treatment.

WITHIN-SUBJECTS A study designed to make a comparison of two or more treatments and that compares them by having each user try each treatment, measuring their performance for each (Diamond Bullet).

BETWEEN-SUBJECTS A study designed to make a comparison of two or more treatments and that compares them by having one set of users try one treatment and another set of users try another treatment, measuring their performance for each (Diamond Bullet).

FACTORIAL EXPERIMENTAL DESIGN A design which enables the effects of two or more independent variables to be explored jointly (Singleton Jr. et al., 1993, p. 225).

CASE STUDY A strategy for doing research which involves an empirical investigation of a particular contemporary phenomenon within its real life context using multiple sources of evidence (Robson, 2002, p. 178).

CROSS-SECTIONAL SURVEY Data on a sample or "cross section" of respondents chosen to represent a particular target population are gathered at essentially one point in time (Singleton Jr. et al., 1993, p. 254).

NON-PARTICIPANT OBSERVATION An approach to field research in which the researcher attempts to observe people without interacting with them and, typically without their knowing that they are being observed (Singleton Jr. et al. 
Appendix 3

General Overview of the Included Articles and Coding

\begin{tabular}{|c|c|c|c|c|c|c|c|c|c|c|c|c|}
\hline $\begin{array}{l}\text { Art. } \\
\text { No. }\end{array}$ & $\begin{array}{l}\text { Technology } \\
\text { used }\end{array}$ & $\begin{array}{l}\text { Language } \\
\text { skills }\end{array}$ & Research design & $\begin{array}{l}\text { Language(s) } \\
\text { taught }\end{array}$ & $\begin{array}{l}\text { Native language of } \\
\text { the partici-pants }\end{array}$ & Setting & $\begin{array}{l}\text { No. } \\
\text { of part- } \\
\text { icipants }\end{array}$ & $\begin{array}{l}\text { Length } \\
\text { of treat- } \\
\text { ment }\end{array}$ & $\begin{array}{l}\text { language } \\
\text { proficiency }\end{array}$ & FB type & $\begin{array}{l}\text { Effective- } \\
\text { ness over } \\
\text { time }\end{array}$ & Gender \\
\hline 1 & $\begin{array}{l}\text { Word processor } \\
\text { (track changes) }\end{array}$ & Writing & Experimental & English & Arabic & College & 64 & 12 weeks & Inter-mediate & explicit \& implicit & Effective & $\begin{array}{l}16 \mathrm{M} \\
48 \mathrm{~F}\end{array}$ \\
\hline 2 & Track changes & Writing & Experimental & English & Arabic & College & 64 & 8 weeks & Inter-mediate & $\begin{array}{l}\text { Track Changes, } \\
\text { Recast \& Meta- } \\
\text { linguistic }\end{array}$ & Effective & $\begin{array}{l}48 \mathrm{~F} \\
16 \mathrm{M}\end{array}$ \\
\hline 3 & $\begin{array}{l}\text { Text-based } \\
\text { Synchronous } \\
\text { CMC }\end{array}$ & $\begin{array}{l}\text { Writing } \\
\text { Speaking }\end{array}$ & Non experimental & $\begin{array}{l}\text { English } \\
\text { Japanese }\end{array}$ & $\begin{array}{l}\text { English } \\
\text { Japanese }\end{array}$ & College & 48 & 6 weeks & $\begin{array}{l}\text { Beginners \& } \\
\text { Advanced }\end{array}$ & NA & Effective & NA \\
\hline 4 & $\begin{array}{l}\mathrm{CMC} / \text { Online } \\
\text { educational } \\
\text { game }\end{array}$ & Speaking & Case Study & English & Dutch & College & 83 & 8 weeks & Inter-mediate & Explicit implicit & Effective & $\begin{array}{l}61 \mathrm{~F} \\
22 \mathrm{M}\end{array}$ \\
\hline 5 & $\begin{array}{l}\text { Automatic } \\
\text { speech } \\
\text { recognition } \\
\text { (ASR) }\end{array}$ & $\begin{array}{l}\text { Speaking } \\
\text { grammar }\end{array}$ & $\begin{array}{l}\text { experimental design, } \\
\text { Non- equivalent } \\
\text { comparison group } \\
\text { design } \\
\text { Questionnaire }\end{array}$ & Dutch & $\begin{array}{l}\text { Dutch } \\
\text { Arabic, Chinese, } \\
\text { Dari, English, } \\
\text { French, German, } \\
\text { Indonesian, Italian, } \\
\text { Russian, Luganda, } \\
\text { Polish, Portuguese, } \\
\text { Romanian }\end{array}$ & $\begin{array}{l}\text { Language } \\
\text { centre }\end{array}$ & 29 & $\begin{array}{l}90 \\
\text { minutes }\end{array}$ & Inter-mediate & Explicit implicit & Effective & Mix \\
\hline 6 & $\begin{array}{l}\text { Online } \\
\text { CMC }\end{array}$ & Speaking & $\begin{array}{l}\text { Non-experimental } \\
\text { design, analysis of } \\
\text { transcript } \\
\text { Questionnaire }\end{array}$ & English & $\begin{array}{l}\text { Chinese Italian, } \\
\text { Indian }\end{array}$ & College & 10 & 8 weeks & Intermediate & Implicit explicit & Effective & $\begin{array}{l}3 \mathrm{M} \\
7 \mathrm{~F}\end{array}$ \\
\hline 7 & $\begin{array}{l}\text { Intelligent } \\
\text { CALL CMC }\end{array}$ & Grammar & $\begin{array}{l}\text { Non-experimental } \\
\text { design/ factorial } \\
\text { experimental design }\end{array}$ & Korean & Korean & College & NA & NA & Beginners & Focused & Effective & NA \\
\hline 8 & CMC Blogs & $\begin{array}{l}\text { Reading Writing } \\
\text { Speaking } \\
\text { Listening }\end{array}$ & $\begin{array}{l}\text { Non-experimental } \\
\text { design, } \\
\text { case study, } \\
\text { questionnaire }\end{array}$ & German & German & College & 12 & NA & Advanced & Peer feedback & Effective & NA \\
\hline 9 & $\begin{array}{l}\text { CM } \\
\text { pronunciation } \\
\text { simultaneous } \\
\text { video, }\end{array}$ & Pronunciation & $\begin{array}{l}\text { Non-experimental } \\
\text { design, case study }\end{array}$ & Swedish & Swedish & NA & 7 & NA & NA & $\begin{array}{l}\text { Audio- } \\
\text { visual Feedback }\end{array}$ & Effective & NA \\
\hline
\end{tabular}




\begin{tabular}{|c|c|c|c|c|c|c|c|c|c|c|c|c|}
\hline 10 & $\begin{array}{l}\text { Synchronous } \\
\text { online } \\
\text { web video- } \\
\text { conferencing } \\
\text { system }\end{array}$ & Writing & $\begin{array}{l}\text { Pre-experimental } \\
\text { design, case study }\end{array}$ & French & French & College & 26 & 7 weeks & Advanced & $\begin{array}{l}\text { Negative feedback } \\
\text { verbal \&written } \\
\text { recasts }\end{array}$ & Effective & NA \\
\hline 11 & $\begin{array}{l}\text { Video- } \\
\text { conference } \\
\text { interactions }\end{array}$ & Grammar & $\begin{array}{l}\text { Pre-experimental } \\
\text { design, Between- } \\
\text { subjects design }\end{array}$ & English & Port-uguese & $\begin{array}{l}\text { Language } \\
\text { Centre }\end{array}$ & 42 & 15 weeks & Beginners & $\begin{array}{l}\text { oral meta-linguistic } \\
\text { feedback \& recasts } \\
\& \text { focused tasks } \\
\text { implicit \& explicit }\end{array}$ & Effective & $\begin{array}{l}27 \mathrm{M} \\
15 \mathrm{~F}\end{array}$ \\
\hline 12 & $\mathrm{CMC}$ & Reading & $\begin{array}{l}\text { Non-experimental } \\
\text { design, case study }\end{array}$ & English & Japanese & College & 267 & NA & $\begin{array}{l}\text { Advanced and } \\
\text { Beginners }\end{array}$ & Elaborative Feedback & Effective & NA \\
\hline 13 & e-portfolios & Writing & $\begin{array}{l}\text { Pre-experimental } \\
\text { design, Case study }\end{array}$ & English & Turkish & School & 20 & 1 year & Beginners & Peer Feedback & Effective & $\begin{array}{l}9 \mathrm{M} \\
11 \mathrm{~F}\end{array}$ \\
\hline 14 & $\begin{array}{l}\text { CALL specific } \\
\text { software }\end{array}$ & Pronunciation & $\begin{array}{l}\text { Pre-experimental } \\
\text { design, non- } \\
\text { equivalent } \\
\text { comparison group } \\
\text { design }\end{array}$ & English & Japanese & $\begin{array}{l}\text { Language } \\
\text { centre }\end{array}$ & 2 & 4 weeks & Intermediate & $\begin{array}{l}\text { Spectro-graphic } \\
\text { visual feedback }\end{array}$ & Effective & $2 \mathrm{~F}$ \\
\hline 15 & $\begin{array}{l}\text { synchronous } \\
\text { written CMC }\end{array}$ & Grammar & $\begin{array}{l}\text { Pre-experimental } \\
\text { design, between- } \\
\text { subject }\end{array}$ & English & $\begin{array}{l}\text { Swedish } \\
\text { Arabic, } \\
\text { Bosnian } \\
\text { Spanish }\end{array}$ & College & 23 & 4 weeks & $\begin{array}{l}\text { High } \\
\text { intermediate } \\
\text { \& Advanced }\end{array}$ & $\begin{array}{l}\text { Recasts } \\
\& \text { meta-linguistic }\end{array}$ & Effective & $\begin{array}{l}4 \mathrm{M} \\
19 \mathrm{~F}\end{array}$ \\
\hline 16 & $\begin{array}{l}\text { Signals } \\
\text { Email }\end{array}$ & $\begin{array}{l}\text { Speaking } \\
\text { Writing }\end{array}$ & $\begin{array}{l}\text { Non-experimental } \\
\text { design, analysis of } \\
\text { transcripts }\end{array}$ & English & Caucasian & College & 8 & 1 year & Advanced & $\begin{array}{l}\text { Implicit } \\
\text { explicit feedback, } \\
\text { Focused } \\
\text { Summative feedback }\end{array}$ & Effective & $\begin{array}{l}4 \mathrm{M} \\
4 \mathrm{~F}\end{array}$ \\
\hline 17 & $\begin{array}{l}\text { Online } \\
\text { reciprocal } \\
\text { peer tutoring }\end{array}$ & Reading Writing & $\begin{array}{l}\text { A quasi-experimental } \\
\text { design, Between- } \\
\text { subjects design, } \\
\text { Analysis of transcript }\end{array}$ & $\begin{array}{l}\text { English } \\
\text { Spanish }\end{array}$ & English Spanish & School & 44 & 5 weeks & Advanced & $\begin{array}{l}\text { Peer } \\
\text { Praise } \\
\text { Question } \\
\text { Prompt } \\
\text { Mark }\end{array}$ & Effective & NA \\
\hline 18 & $\begin{array}{l}\text { CMC e-mail } \\
\text { exchange }\end{array}$ & Writing & $\begin{array}{l}\text { Non- } \\
\text { Experimental, } \\
\text { Within-Subject, } \\
\text { Analysis of transcript, } \\
\text { questionnaire }\end{array}$ & $\begin{array}{l}\text { Spanish } \\
\text { German }\end{array}$ & Spanish German & School & 10 & 12 weeks & Advanced & peer feedback & Effective & $\begin{array}{l}3 \mathrm{M} \\
7 \mathrm{~F}\end{array}$ \\
\hline 19 & $\begin{array}{l}\text { Automatic } \\
\text { speech } \\
\text { recognition }\end{array}$ & $\begin{array}{l}\text { Speaking } \\
\text { Pronunciation }\end{array}$ & $\begin{array}{l}\text { A quasi-experimental } \\
\text { design }\end{array}$ & English & Chinese & $\begin{array}{l}\text { College } \\
\text { school }\end{array}$ & 34 & 8 weeks & Intermediate & $\begin{array}{l}\text { formative summative } \\
\text { implicit explicit }\end{array}$ & Effective & $\begin{array}{l}18 \mathrm{~F} \\
16 \mathrm{M}\end{array}$ \\
\hline 20 & $\begin{array}{l}\text { Synchronous } \\
\text { text chat }\end{array}$ & Speaking & $\begin{array}{l}\text { Non- experimental } \\
\text { design, Factorial }\end{array}$ & $\begin{array}{l}\text { French } \\
\text { English }\end{array}$ & $\begin{array}{l}\text { English } \\
\text { French }\end{array}$ & college & 17 & 5 days & Intermediate & $\begin{array}{l}\text { Recast } \\
\text { Reinforcement }\end{array}$ & Effective & $\begin{array}{l}8 \mathrm{~F} \\
9 \mathrm{M}\end{array}$ \\
\hline
\end{tabular}




\begin{tabular}{|c|c|c|c|c|c|c|c|c|c|c|c|c|}
\hline & & & $\begin{array}{l}\text { experimental design, } \\
\text { Analysis of transcript }\end{array}$ & & $\begin{array}{l}\text { Spanish Chinese } \\
\text { Italian } \\
\text { Korean Arabic }\end{array}$ & & & & & $\begin{array}{l}\text { Explicit } \\
\text { Meta-linguistic } \\
\text { information } \\
\text { Clarification request }\end{array}$ & & \\
\hline 21 & Online CMC & Writing & $\begin{array}{l}\text { Pre-experimental } \\
\text { design, within subject } \\
\text { design }\end{array}$ & English & Chinese & College & 50 & 12 weeks & $\begin{array}{l}\text { Advanced \& } \\
\text { Intermediate }\end{array}$ & Peer online Feedback & Effective & NA \\
\hline 22 & $\begin{array}{l}\text { Online } \\
\text { Annotator/ } \\
\text { CALL Specific } \\
\text { software }\end{array}$ & Writing & $\begin{array}{l}\text { experimental design, } \\
\text { Between-subjects }\end{array}$ & English & Chinese & College & 50 & NA & Beginners & $\begin{array}{l}\text { Meta-linguistic } \\
\text { feedback } \\
\text { Explicit }\end{array}$ & Effective & NA \\
\hline 23 & $\begin{array}{l}\text { Synchronous \& } \\
\text { A synchronous } \\
\text { CMC }\end{array}$ & Communication & $\begin{array}{l}\text { non-experimental } \\
\text { design }\end{array}$ & French & $\begin{array}{l}\text { French } \\
\text { Spanish }\end{array}$ & NA & $\mathrm{NA}$ & NA & $\begin{array}{l}\text { Advanced \& } \\
\text { Intermediate }\end{array}$ & $\begin{array}{l}\text { Online feedback } \\
\text { focus on form }\end{array}$ & Effective & $\mathrm{NA}$ \\
\hline
\end{tabular}

